\title{
MODEL PERJANJIAN EFEKTIF UNTUK MENGURANGI TINGKAT RESIKO DALAM PEMBIAYAAN MUDHARABAH PADA BANK SYARIAH
}

\author{
Luthfiyah Trini Hastuti; Burhanudin Harahap; Solikhah \\ Fakultas Hukum Universitas Sebelas Maret Surakarta \\ Email : luthfiyahth@gmail.com; burhanudin60@gmail.com; solikhah@uns.ac.id
}

\begin{abstract}
Mudaraba is a cooperative institution agreed by jurists in lieu of debts or borrowing in the banking feared contain elements of usury. In a period of more than ten years, it was financing is not optimal as expected by the scientists of Islamic law. Research for this first year aims; (1) Inventory overview of Islamic banking desire to give of financing; (2) review the description of Islamic banking desire to give of financing; (3) Develop forms of legal protection that is ideal to be used as a model in reducing the level of risk faced by the Islamic banking in providing of financing; (4) Develop a model agreement ideal for Islamic banking in order to improve the provision of financing to customers. This study is an empirical research related to the identification and effectiveness of the law. The data used are primary data and secondary data. The primary data obtained through interviews and focus group discussions. Secondary data were obtained through library research related to the problem under study. Analyses were performed using content analysis (content analysis), which examines the contents of mudaraba cooperation. The results showed that; (1) In principle, Islamic banking has committed to provide financing is optimal; (2) the desire to provide optimal financing constraints facing many complex factors, ranging from the issue of the system to issue public unprepared to accept it; that society is pragmatic and less understand the real nature of mudaraba; (3) Islamic banks need to receive adequate legal protection for accounts receivable financing is not given in the form of a dishonest act of the customer; (4) model is ideal agreement of financing by Islamic banking is; $(A)$ the customer in the form of the company because it is easy to mlakukan supervision; (B) similar business field.
\end{abstract}

Keywords: mudaraba, agreement, cooperation, legal protection

\begin{abstract}
Abstrak
Mudharabah adalah pranata kerjasama yang disepakati oleh para ahli hukum Islam sebagai pengganti utang piutang atau pinjam meminjam dalam perbankan yang dikhawatirkan mengandung unsur riba. Dalam kurun waktu lebih dari sepuluh tahun ternyata pembiayaan mudharabah tidak optimal sebagaimana yang diharapkan oleh para ilmuwan hukum Islam. Penelitian ini bertujuan; (1) Menginventarisasi gambaran keinginan perbankan syariah dalam memberikan pembiayaan mudharabah; (2) mengkaji gambaran keinginan perbankan syariah dalam memberikan pembiayaan mudharabah; (3) Menyusun bentuk-bentuk perlindungan hukum yang ideal untuk dijadikan model dalam mengurangi tingkat resiko yang dihadapi perbankan syariah dalam memberikan pembiayaan mudharabah; (4) Menyusun model perjanjian yang ideal bagi perbankan syariah agar dapat meningkatkan pemberian pembiayaan mudharabah kepada nasabah. Penelitian ini merupakan penelitian empiris yang berkait dengan identifikasi dan efektivitas hukum. Data yang dipergunakan adalah data primer yang diperoleh dengan wawancara dan focus group discussion dan data sekunder yang diperoleh melalui studi kepustakaan yang berkait dengan persoalan yang dikaji lalu dianalisis dengan menggunakan analisis isi (content analysis), yaitu mengkaji isi kerjasama mudharabah. Hasil penelitian menunjukkan bahwa; (1) Pada prinsipnya perbankan syariah mempunyai mempunyai komitmen untuk memberikan pembiayaan mudharabah secara optimal; (2) keinginan untuk memberikan pembiayaan secara optimal menghadapi kendala berbagai faktor yang kompleks, mulai dari persoalan sistem sampai persoalan ketidaksiapan masyarakat untuk menerimanya; yaitu masyarakat bersifat pragmatis dan kurang memahami hakekat yang sebenarnya tentang mudharabah; (3) Perbankan syariah perlu mendapat perlindungan hukum secara memadai karena pembiayaan mudharabah tidak berbentuk piutang yang diberikan dari perbuatan yang tidak jujur dari nasabah; (4) Model perjanjian ideal pembiayaan mudharabah oleh perbankan syariah adalah; (a) nasabah berbentuk perusahaan karena mudah untuk mlakukan pengawasan; (b) bidang usaha yang sejenis;
\end{abstract}

Kata kunci: mudharabah, perjanjian, kerjasama, perlindungan hukum. 


\section{A. Pendahuluan}

Mudharabah (profit sharing) adalah sebuah pranata hukum yang direkomendasikan para ilmuwan Islam sebagai instrumen untuk mereorganisasi dan merekonstruksi perbankan lembaga keuangan perbankan. Dalam kaitannya sebagai sarana penghimpunan dana (funding) dari masyarakat maupun sebagai sarana menyalurkan kembali kepada masyarakat (financing) (Muhammad Nejatullah Siddiqi, 1985: 9).. Ini berarti bahwa mudharabah dijadikan jargon para ilmuwan Islam sebagai pranata pokok dan utama untuk menggerakan roda perbankan Syariah.

Begitu terkenalnya mudharabah sebagai sistem bagi hasil, sehingga pada awal pembentukan perbankan syariah, nama tersebut digunakan untuk menyebut identitas perbankan, sehingga terkenal dengan bank bagi hasil. Bahkan Undang-undang perbankan yaitu Undang-undang No. 7 tahun 1992 dan Peraturan Pemerintah No. 72 tahun 1992 menyebut bagi hasil untuk membedakan dengan bank yang menggunakan instrumen bunga.

Reorganisasi dan rekonstruksi perbankan dengan mudharabah pada dasarnya bukan tanpa alasan. Penggunaan mekanisme perbankan dengan mudharabah adalah sangat ideal. Secara konseptual instrumen mudharabah ini sangat potensial bagi usaha menggerakkan sektor ekonomi riil yang selama ini menjadi idam-idaman para praktisi ekonomi. Pembiayaan mudharabah dapat menumbuhkan dan mendorong semangat berusaha, sehingga dapat menimbulkan mata rantai yang dapat menciptakan lapangan kerja baru.

Dalam praktek, penggunaan instrumen mudharabah sebagai sarana untuk mereorganisasi dan merekonstruksi perbankan baru berhasil digunakan sebagai mekanisme penghimpunan dana dari masyarakat (funding). Mudharabah belum dijadikan andalan perbankan syariah dalam memberikan pembiayaan kepada masyarakat (financing). Persoalan ini tidak hanya terjadi di Indonesia saja, tetapi terjadi hampir di seluruh perbankan yang ada di seluruh penjuru dunia (Mervyn K Lewis dan Latifa M Algaout, 2001: 134)

Dalam perspektif hubungan hukum, mudharabah merupakan hubungan hukum kerjasama. Bukan hubungan hukum utang piutang dan bukan pula sebagai hubungan hukum pinjam meminjam. Hubungan hukum kerjasama menempatkan para pihak yang terkait di dalamnya dalam posisi atau kedudukan yang sama, meskipun masing-masing mempunyai fungsi yang berbeda. Perbankan dalam posisinya sebagai pemilik modal mempunyai fungsi dan peran memberikan modal untuk dimanfaatkan dalam kegiatan bisnis. Sedangkan nasabah dalam posisinya sebagai pelaku usaha menjalankan fungsinya untuk bekerja mengelola dana yang telah diberikn oleh perbankan dalam bentuk pembiayaan mudharabah.

Filsafat kerjasama mudharabah dalam pembiayaan, menempatkan bank syariah sebagai pemilik modal, mempunyai kedudukan yang seimbang atau setara atau sederajad dengan nasabah. Hubungan bank syariah dengan nasabah bukan dalam posisi sebagai kreditur dan debitur. Dalam logika dunia perbankan konvensional yang menguasai cara berpikir dunia perbankan, hubungan dalam mudharabah menempatkan perbankan pada posisi yang sangat beresiko memberikan pembiayaan dalam bentuk mudharabah. Resiko yang harus ditanggung begitu tinggi dalam pembiayaan mudharabah.

Tingginya tingkat resiko inilah yang menjadi dasar untuk melakukan penelitian. Dimulai dengan usaha mengidentifikasi persoalan yang yang dihadapi dan keinginan-keinginan perbankan syariah dalam memberikan pembiayaan dalam bentuk mudharabah, untuk kemudian dianalisis dicari jalan keluar untuk menemukan model pembiayaan mudharabah yang ideal bagi perbankan Syariah.

\section{B. Metode penelitian}

Penelitian ini adalah penelitian empiris yang terdiri dari penelitian terhadap identifikasi hukum dan penelitian terhadap efektivitas hukum. Maksudnya adalah mengaitkan hukum kepada usaha untuk mencapai tujuan-tujuan serta memenuhi kebutuhan konkret dalam masyarakat (Soerjono Soekanto:2005:51). Penelitian ini bersifat kualitatif yang bersifat deskriptif, yaitu untuk mengidentifikasi adanya faktor-faktor yang menjadi hambatan bagi perbankan syariah memberikan pembiayaan mudharabah, sehingga dapat dicari model yang ideal bagi perbankan Syariah. Penelitian dilakukan di Kota Surakarta, Kabupaten Sukoharjo, Kabupaten Boyolali, Kabupaten Sragen, Kabupaten Karanganyar, yaitu di semua kantor cabang bank syariah dan bank konvensional yang membuka cabang Syariah (Islamic Windows)

Data yang digunakan meliputi data primer yang diperoleh secara langsung dari lapangan. Data ini berupa penjelasan atau keterangan atau jawaban atas daftar pertanyaan yang diajukan. Data ini berusaha untuk diperoleh 
melalui wawancara secara terstruktur. Data sekunder yang digunakan di dalam penelitian ini adalah dokumen perjanjian mudharabah, literatur-literatur dan sumber sumber tertulis lain yang mempunyai kaitan dengan permasalahan perjanjian mudharabah pada perbankan syariah. Untuk memperoleh data yang valid, maka langkahlangkah yang dilakukan dalam penelitian ini adalah sebagai berikut: 1) Pengumpulan data melalui studi pustaka dilakukan terhadap pengertian-pengertian yang bersifat umum atau teknis seperti yang ada di dalam kamus dan ensiklopedi 2) Menelaah dokumen perjaanjian pembiayaan mudharabah.

3) Wawancara dilakukan secara terstruktur agar pertanyaan-pertanyaan yang diajukan dapat dilakukan secara sistematis. Dengan susunan pertanyaan yang sistematis, diharapkan dapat memperoleh jawaban yang sistematis pula. 4) Focus Group Discussion (FGD) dilakukan untuk memperoleh pikiran dan pandangan dari pihakpihak yang mempunyai kompetensi di bidang hukum transaksi dan keuangan Islam kaitannya dengan sistem pembiayaan mudharabah . Analisis data di dalam penelitian deskriptif ini akan menggunakan analisis isi (content analysis). Untuk menjaga kesahihan data primer maka dilakukan triangulasi data, yaitu data yang telah diperoleh dari suatu sumber dibandingkan dengan data dari sumber yang lain. Sedangkan terhadap data sekunder, dilakukan kritik sumber.

\section{Hasil Penelitian Dan Pembahasan}

1. Keinginan perbankan syariah dalam memberikan pembiayaan mudharabah

Hubungan hukum mudharabah antara bank Islam dengan nasabah adalah sedemikian rupa kompleks, sehingga dibutuhkan pesyaratan tertentu yang tidak mudah sebagaimana dalam hubungan hukum dalam pembiayaan yang berbasis pinjaman atau utang sebagaimana pembiayaan yang dilakukan antara perbankan konvensional dengan nasabah yang relatif sederhana.

Hubungan hukum mudharabah memerlukan persyaratan-persyaratan yang khusus yang tidak sepenuhnya dapat dipercayakan kepada hukum saja untuk mengatur. Pengaturan secara hukum terhadap perjanjian mudharabah tidak menjamin adanya efektivitas mudharabah. Hal ini disebabkan oleh faktor-faktor yang tidak sepenuhnya dapat diatur secara hukum.

\section{Problem perbankan syariah dalam} memberikan pembiayaan mudharabah.
Pembiayaan mudharabah tidak dapat terjadi hanya atas inisiatif sepihak oleh perbankan. Kemauan pihak untuk memberikan pembiayaan mudharabah tidak dapat terlaksana hanya karena diterima begitu saja oleh nasabah yang akan dibiayai sebagaimana dapat dengan mudah terjadi pada pembiayaan berbasis pinjaman atau utang yang dilaksanakan oleh perbankan konvensional. Terjadinya mudharabah harus ada dua kekuatan yang bersinergi, yaitu kekuatan modal dan kekuatan keahlian atau profesionalitas. oleh karena itu dapat dengan mudah difahami mengapa pembiayaan mudharabah relatif sangat sedikit, yang dipengaruhi oleh beberapa faktor yang dapat dijelaskan sebagai berikut:

a. Faktor Eksternal

1) Permohonan pembiayaan mudharabah sedikit.

Sedikitnya pembiayaan mudharabah yang dilakukan oleh perbankan Syariah antara lain karena sedikitnya pemohon (mudharib) yang mengajukan pembiayaan kepada perbankan syariah. Ini menunjukkan bahwa masyarakat belum sepenuhnya dapat menerima mekanisme pembiayaan yang menggunakan pranata hukum mudharabah.

Belum diterimanya mekanisme pembiayaan mudharabah oleh masyarakat dapat difahami karena; (1) mudharabah merupakan pranata hukum yang tidak berakar dari realitas kehidupan masyarakat di Indonesia; (2) Mudharabah merupakan pranata hukum yang relatif baru dibanding dengan pranata utang atau pinjaman yang sudah sedemikian familier dalam kehidupan masyarakat, baik dalam kaitannya dengan pembiayaan yang bersifat produktif maupun konsumtif. oleh karena itu belum banyak dikenal oleh masyarakat luas. Masyarakat belum terbiasa menggunakan pranata mudharabah untuk pembiayaan suatu usaha.

2) Budaya pinjam-meminjam dan utang piutang di dalam masyarakat.

Sedikitnya permohonan pembiayaan mudharabah dari mudharib atau pelaku usaha dapat difahami karena masyarakat terbiasa 
dengan budaya pinjaman dan utang. Mendarahdagingnya utang piutang atau pinjam meminjam di dalam kehidupan masyarakat juga dapat dengan mudah difahami Karen pranata hukum ini begitu mudah, baik secara konseptual maupun aplikasinya. Pranata ini sangat efisien dan efektif dapat memenuhi segala macam keperluan dan kebutuhan manusia, baik yang bersifat produktif maupun konsumtif.

Sementara mudharabah merupakan pranata hukum yang rumit, dengan fungsi yang terbatas untuk keperluan bisnis saja. Bidang bisnis yang dapat dibiayai oleh mudharabah pun sangat terbatas. Tidak semua bidang bisnis layak dibiayai dengan mudharabah. Mudharabah hanya layak untuk pembiayaaan jenis usaha tertentu, terutama dalam dunia perdagangan jangka pendek. Dengan demikian mudharabah kurang diminati masyarakat. Masyarakat kurang antusias.

3) Kurang budaya bekerjasama dalam mencari keuntungan

Pengertian mudharabah sebagai sebuah pranata kerjasama dalam mencari keuntungan merupakan pengerian kerjasama yang sebenarnya secara sinergis. Yaitu sinergis antara pemilik modal (perbankan) dan orang yang mempunyai keahlian atau profesionalitas.

Masyarakat jawa yang terkenal dengan gotong royong merupakan pengertian kerjasama dalam bidang sosial kemasyarakatan. Bukan kerjasama dalam mencari keuntungan.

Kerjasama mencari keuntungan dalam Perseroan Terbatas atau cV hanyalah kerjasama antara para pemilik modal dengan pemilik modal yang lain secara individual. Demikian juga kerjasama dalam koperasi. Kerjasama dalam koperasi adalah kerjasama yang lebih menitik beratkan kepada pemenuhan kebutuhan, bukan untuk mencari keuntungan. Meskipun kemudian di dalam koperasi ada orientasi keuntungan, namun hal ini tetap merupakan kumpulan orang dengan sebagian modal untuk dari anggota untuk anggota. Bukan merupakan kerjasama dua kekuatan, kekuatan modal dan kekuatan keahlian atau profesionalitas untuk bersinergi dalam satu usaha untuk mencari keuntungan, yang sinergis antara pemilik modal di satu pihak dan pelaku usaha pada pihak lain.

4) Pelaku usaha lebih merasa nyaman berspekulasi secara sendiri-sendiri.

Kurang tertariknya masyarakat untuk mendapatkan pembiayaan mudharabah dipengaruhi oleh perilaku ekonomi masyarakat yang lebih merasa leluasa melakukan usaha bisnis secara mandiri. Pengaturan yang ketat dalam mudharabah dirasakan sebagai membatasi usaha yang dilakukan. Masyarakat merasa kurang bebas dalam berusaha untuk mencari keuntungan dengan pembiayaan mudharabaah. Pembat asanpembatasan yang ketat dalam mudharabah dirasakan sebagai pembatasan dalam mencari keuntungan.

Secara konseptual pembatasan-pembatasan dalam mudharabah pada dasarnya justru untuk mewujudkan efektivitas mudharabah. Namun dalam kenyataan justru diterima sebagai kurang memberikan keleluasaan dalam mencari keuntungan dalam berbisnis. Masyarakat tidaksiap dengan membagi untung.

5) Rumitnya pembiayaan mudharabah Model penentuan jumlah keuntungan pada akhir pembiayaan sebagaimana yang dikonsepkan dalam pembiayaan mudharabah dalam kenyataan dianggap kurang praktis oleh masyarakat. Masyarakat lebih menyukai penentuan pembayaran keuntungan secara nominal dari pada penentuan keuntungan secara nisbah atau porsi. Pelaku usaha lebih berpikir pragmatis, sehingga penentuan keuntungan dengan nisbah dianggap sebagai ketidakpastian yang tidak praktis. 
cara berpikir pragmatis demikian inilah yang mengakibatkan adanya pernyataanpernyataan yang menyebutkan bahwa pembiayaan mudharabah lebih mahal dari pada pembiayaan di bank konvensional. Logika ini terjadi karena tidak mengetahui sistem yang berlaku di dalam mudharabah, bahwa; (1) jika pelaku usaha memperoleh keuntungan yang besar tentu saja keuntungan yang harus dibagi kepada perbankan syariah juga besar; (2) jika keuntungan yang diperoleh pelaku usaha sedikit tentu saja keuntungan yang diberikan kepada ke perbankan syariah juga sedikit; (3) jika memang pelaku usaha tidak memperoleh keuntungan dari mudharabah yang dilakukan, tentu saja juga tidak memberikan bagian keuntungan kepada bank syariah; (4) jika pelaku usaha menderita kerugian yang murni bersifat ekonomis dan bukan akibat kesalahannya, tentu saja yang akan menanggung kerugian uang adalah perbankan syariah. Pembiayaan untuk bisnis yang diberikan oleh perbankan konvensional dirasakan lebih murah dari pada pembiayaan mudharabah dari perbakan syariah, tentu saja dirasakan lebih menguntungkan pelaku usaha. Sebaliknya pembiayaan mudharabah yang lebih mahal dirasakan sebagai kerugian karena perolehan keuntungan yang lebih sedikit.

Persoalan ini menunjukkan bahwa masyarakat belum siap menerima pranata mudharabah sebagai sebuah kerjasama. Masyarakat hanya berfikir pragmatis ekonomis. Masyarakat tidak berpikir secara konseptual dan sistematik. oleh karena itu jika pelaku usaha mempunyai keuntungan yang besar tentu sajajuga harus memberi keuntungan bagi hasil yang besar juga kepada perbankan. Sebaliknya jika terjadi kerugian yang murni karena kerugian ekonomis tentu saja perbankan yang akan menanggung kerugian finansial. Pelaku usaha akan menanggung kerugian waktu, pekerjaan dan keahlian. Resiko yang demikian inilah yang belum bisa difahami dan diterima masyarakat. Padahal ini sesuai dengan teori dalam ilmu ekonomi bahwa makin tinggi tingkat resiko makin tinggi tingkat keuntungan yang harus didapatkan.

\section{Faktor internal}

a. Resiko yang tinggi dalam pembiayaan mudharabah

Sebagai bentuk kerjasama, pembiayaan mudharabah bagi perbankan mengandung resiko yang tinggi. Dalam kedudukannya sebagai pemilik dana, perbankan harus menanggung semua kerugian finansial yang diderita oleh nasabah yang dibiayainya dengan syarat kerugian yang diderita nasabah murni kerugian yang bersifat ekonomis, sedangkan nasabah yang dibiayai menanggung kerugian waktu, tenaga, keahlian dan sebagainya yang bentuknya bukan finansial.

Meskipun pembiayaan mudharabah yang diberikan kepada nasabah mensyaratkan adanya jaminan, tetapi secara hukum jaminan yang diberikan oleh nasabah kepada perbankan bukan menjamin pembiayaan mudharabah sebagaimana yang ada dalam pembiayaan dalam bentuk pinjaman dalam perbankan konvensional.

Jaminan d a I a m mudharabah hanya dapat dilelang untuk melunasi pembiayaan, jika nasabah melakukan pelanggaran kesepakatan, penipuan, kelalaian kekurang hatian dan sebagainya yang berakibat adanya kerugian. Perbankan Islam tidak dapat dibebani kerugian finansial yang disebabkan oleh kesalahanatau penipuan atau kelalaian atau pelanggaran terhadap perjanjian mudharabah yang disepakati. Namun demikian tetapi perbankan harus melakukan pengawasan secara ketat agar nasabah tidak melakukan hal-hal yang dapat merugikan usaha kerjasama yang dibiayai perbankan Islam. Tetap saja mempunyai resiko yang besar dibanding dengan pembiayaan dalam bentu pinjaman atau utang

b. Pengalaman menerapkan mudharabah masih relatif sedikit

Di Indonesia, perbankan Islam baru ada mulai tahun 1992. Sampai dengan sekarang relatif masih baru. oleh karena itu pengalaman memberikan pe mbiayaan mudharabah pun relatif masih sedikit. Pemberian pembiayaan mudharabah memerlukan pengalaman panjang sesuai dengan taraf perkembangan pemikiran 
masyarakat yang secara relatif juga baru mengenal.

Perbankan Islam tidak dapat dipaksakan untuk mengoptimalkan pembiayaan mudharabah kepada masyarakat karena perbankan Islam memerlukna proses bersosialisasi dengan masyarakat yang akan dibiayai. oleh karena itu perbankan Islam berdasarkan pengalaman harus secara terus menerus dan simultan mengembangkan pembiayaan mudharabah kepada masyarakat agar dapat efektif dan efisien, mempunyai nilai kemaslahatan dari sisi ketuhanan dan kemanusiaan.

\section{Faktor sistem}

a. Sistem perbankan nasional yang melarang lembaga perbankan melakukan kegiatan usaha di luar sektor keuangan.

Pembedaan sektor riil dan keuangan dalam sistem perekonomian di Indonesia mengharuskan dunia perbankan hanya boleh menjalankan usaha dalam sektor keuangan saja. Sistem perbankan di Indonesoia yang demikian sekedar mengadopsi konsep perbankan barat yang berbasis pinjam meminjam dengan bunga. Dengan demikian pembiayaan yang dilakukan memang merupakan sebuah sistem keuangan murni.

Menurut hukum Islam, bunga mengandung unsur riba yang dilarang secara keras dan diharamkan. oleh karena itu secara konseptual akademik perbankan Islam menghadapi tantangan persoalan yang bersifat sistemik. Di satu sisi sistem perbankan di Indonesia hanya memperbolehkan perbankan melakukan usaha di sektor keuangan saja, sementara pada sisi yang lain sistem hukum Islam tidak memberikan ruang bergerak untuk menjalankan usaha yang berorientasi mencari keuntungan dalam bentuk pinjaman atau utang yang murni dalam bidang keuangan saja.

Meskipun persoalan sistemik dapat dicarijalan keluar dengan menggunakan pranata-pranata hukum islam dunia ekonomi riil murni, namun karena dalam dunia keuangan adalah sedemikian rupa maka tetap saja menggunakan pendekatan pragmatis. Pendekatan pragmatis inipun tidak mudah dalam pengaplikasiannya. Meskipun terus dilakukan inovasi-inovasi penggunaan pranata ekonomi riil dalam dunia keuangan murni seperti di Indonesia, namun tetap saja akan menimbulkan persoalan, baik secara konsep, sistem maupun aplikasinya.

Bagi masyarakat, persoalan sistemik tidak difahami sebagai sebuah sistem, tetapi justru difahami pada tingkat implikasinya dalam bentuk pembiayaan-pembiayaan dengan segala relevansinya, terutama dilihat dari aspek ekonomis semata. Munculnya ungkapan bahwa bank Islam sama saja dengan bank konvensional untuk mencari keuntungan, bank Islam justru tidak islami karena lebih mahal dari perbankan konvensional dan sebagainya merupakan contoh akibat sebuah sistem yang harus disandang oleh bank Islam di Indonesia.

b. Pengawasan yang ketat terhadap pembiayaan mudharabah yang dilakukan oleh Bank Indonesia

Dalam kapasitasnya sebagai pengawas, bank Indonesia melakukan pengawasan terhadap semua perbankan termasuk bank Islam. Terhadap pembiayaan mudharabah yang dilakukan perbankan Syariah, bank Indonesia mengasasi secara ketat. Logikanya adalah bahwa bank sebagai sebuah lembaga keuangan adalah membutuhkan tingkat kepercayaan yang tinggi dari masyarakat. Untuk itu bank harus menerapkan kehatihatian tingkat tinggi, sehingga terhadap pembiayaan mudharabah bank Indonesia mengawasi secara khusus, berbeda dengan pengawasan terhadap pembiayaan yang berbasis utang atau pinjaman.

c. Kesulitan menggunakan pranata hukum riil di dalam dunia keuangan 
Penggunaan pranata hukum dunia ekonomi riil dalam dunia keuangan perbankan di Indonesia tidak selamanya dapat diselesaikan dengan baik. Penggunaan pranata hukum Islam dalam lembaga keuangan secara normatif telah dapat diselesaikan oleh Dewan Syariah Nasional Majlis Ulama Indonesia. Pada tingkat penerapannya diawasi oleh Dewan Pengawas Syariah pada bank Islam yang bersangkutan.

Pada tingkat penerapan ini pengawasan kesyariahan hanya dilihat dari sisi perjanjian formal dalam bentuk perjanjian baku pada setiap perbankan Islam. Dewan Pengawas Syariah inipun hanya ada di kantor pusat. Tidak ada di kantor cabang. Ini berarti bahwa pada tingkat reaalisasi dari pranata hukum tidak mendapatkan pengawasan. oleh karena itu dapat dikatakan bahwa pengawasan kesyariahan hanya bersifat formal, sehingga kurang menyentuh aspek kesyariahan yang bersifat materiil berkait dengan kebutuhan bisnis masyarakat yang sangat berbedabeda dan beragam.

Dalam bentuk pengawasan yang demikian, maka pemberian pembiayaan mudharabah di kantorkantor cabang akaan dirasakan sebagai sangat kaku, sehingga tidak memberikan kesempatan inovasi dalam pembiayaan mudharabah sesuai dengan realitas perkembangan dan kebutuhan masyarakat.

\section{Efektivitas Pembiayaan Mudharabah}

a. Pemilihan jenis usaha yang dibiayai mudharabah

Tingkat resiko perbankan yang tinggi dalam memberikan pembiayaan mudharabah, mengharuskan perbankan harus selektif dalam memberikan pembiayaan mudharabah. Tidak setiap usaha dapat diberikan pembiayaan mudharabah. Hal ini disebbkan karena secara konseptual tidak semua bidang usaha cocok untuk dibiayai dengan mudharabah.
Mudharabah hanya cocok untuk usaha tertentu.

Mudharabah hanya cocok untuk pembiayaan-pembiayaan perdagangan dan kntrak-kontrak usaha jangka pendek sebagaimana yang diterapkan oleh perbankan dalam memberikan pembiayaan mudharabah kepada kontraktor yang mendapatkan kontrak membangun manufaktur. Demikian juga kontarktor yang membangun jalan, relatif mudah untuk dibiayai dengan mudharabah.

Pemberian pembiayaan mudharabah tanpa melakukan seleksi bidang usaha akan sulit dilaksanakan, sulit diawasi dan sulit juga mengakhirinya. Dalam keadaan yang demikian maka pembiayaan mudharabah akan terkatungkatung dalam ketidakjelasan yang pada akhirnya akan merugikan keduabelah pihak, baik perbankan maupun nasabah yang dibiayai. oleh karena itu dengan pemilihan terhadap jenis atau bidang usaha tertentu yang dibiayai dengan mudharabah diharapkan dapat melaksanakan, mengawasi dan mengakhiri mudharabah tanpa ada persoalan yang berarti

b. Pemlihan jenis mudharabah

Bank Islam sebagai lembaga intermediasi menerima dana dan menyalurkan kembali kepada masyarakat. Penerapan pranata hukum Islam dalam lembaga keuangan perbankan memerlukan strategi pemilihan pranata-pranata hukum Islam yang cocok sesuai dengan karakteristik hubungan yang diciptakannya. Tidak semua pranata hukum Islam dapat digunakan untuk semua hubungan hukum yang diciptakannya. Demikian juga tidak semua jenis mudharabah dapat efektif untuk pembiayaan kepada pelaku usaha.

Dalam memberikan pembiayaan mudharabah, perbankan syariah hanya efektif menerapkan jenis mudharabah muqayyadah. Yaitu mudharabah dengan persyaratan dan pembatasan tertentu. Ini perlu dilakukan agar pembiayaan yang 
diberikan kepada nasabah sesuai dengan apa yang disepakati antara pihak perbankan dan nasabah sehingga mengurangi resiko bagi perbankan.

Pemberian pembiayaan mudharabah yang tidak ada persyaratan dan pembatasan akan berpotensi terjadi penyimpangan dari kesepakatan antara bank dan nasabah. Jika ini terjadi maka akan merugikan pihak perbankan.

c. Pemilihan subyek hukum yang dibiayai dengan mudaharabah

Untuk mengurangi tingkat resiko yang tinggi dalam memberikan pembiayaan mudharabah kepada nasabah, perbankan perlu melakukan seleksi terhadap calon nasabah. Pemilihan calon nasabah yang akan dibiayai dengan mudharabah dilakukan dengan persyaratan yang ketat

d. Pengawasan pembiayaan mudharabah

Dana perbankan yang telah diberikan kepada nasabah dalam bentuk pembiayaan mudharabah secara langsung berada dalam kekuasaan nasabah. Pemberian pembiayaan dalam bentuk kerjasama mudharabah, mengharuskan perbankan dalam batas tertentu melakukan pengawasan.

Pengawasan yang dilakukan oleh perbankan dalam kerjasama mudharabah bertujuan agar nasabah; (1) mentaati perjanjian mudharabah yang telah disepakati bersama; (2) Tidak melakukan perbuatan-perbuatan yang dapat merugikan usaha yang dibiayai dengan mudharabah; (3) Tidak melakukan kelalaian yang dapat merugikan usaha yang dibiayai dengan mudharabah.

Pengawasan mempunyai arti sangat penting di dalam pembiayaan mudharabah, karena dana yang diberikan perbankan Islam kepada nasabah adalah dalam bentuk kerjasama. Bukan pinjaman atau utang. Nasabah tidak dalam posisi meminjam atau utang. Posisi nasabah adalah mitra kerjasama.
Dalam kedudukannya sebagai mitra perbankan, maka nasabah dalam posisi sederajad atau seimbang dengan bank sebagai penyandang dana. Hubungan antara perbankan yang memberikan dana dengan nasabah yang dibiayai dengan mudharabah adalah hubungan kemitraan. Bukan hubungan sebagai kredikur dan debitur.

4. Bentuk-bentuk perlindungan hukum yang ideal untuk dijadikan model dalam mengurangi tingkat resiko yang dihadapi perbankan syariah pemberian pembiayaan mudharabah.

a. Pemberian pembiayaan dengan akta notariil

Mudharabah merupakan kerjasama yang penuh dengan asymmetric information, yaitu suatu hubungan yang terjadi karena perbedaan informasi yang dimiliki masing masing pihak dalam mudharabah. Pada satu segi memiliki uang dan yang lain memiliki keahlian. Namun demikian karena kuatnya landasan moralitas yang timbul karena adanya hubungan sedemikian personal yang dalam taraf tertentu dapat diketahui kepribadian masing-masing, sehingga mudharabah pada masa itu sebagai pranata yang efektif dan efisien.

Efektifitas kerjasama mudharabah ditentukan oleh banyak faktor, tetapi faktor moralitas merupakan faktor dominan. Faktor moralitas nasabah yang dibiayai dengan mudharabah merupakan faktor yang paling penting untuk diketahui perbankan. Dengan diketahuinya moralitas nasabah maka nasabah dapat menempatkan diri untuk menjalankan usaha yang dananya seratur persen milik perbankan. Dalam konteks yang demikian inilah dapat tercipta hubungan personal yang sedemikian rupa yang menjadikan perbankan percaya kepada nasabah untuk dibiayai dengan mudharabah.

Perkembangan kehidupan masyarakat sekarang adalah sedemikian rupa, mulai dari masalah 
banyaknya manusia, kompleksnya kehidupan, sampai begitu terbuka masyarakat, sehingga hubungan personal yang menjadi dasar efektivitas mudharabah tidak sepenuhnya dapat dilakukan. Padahal pengetahuan tentang calon nasabah adalah sangat penting dalam pembiayaan mudharabah, karena calon nasabah dalam hal ini merupakan mitra kerja bank. Jika mitra kerja tidak dapat dipercara dan tidak dapat dipertanggung jawabkan maka pembiayaan mudharabah akan gagal, tidak efektif dan tidak efisien, bahkan menimbulkan masalah. oleh karena itu sebelum memberikan pembiayaan mudharabah kepada nasabah, perbankan Syari'ah secara formal melakukan penilaian tentang calon nasabah. Penilaian yang dilakukan oleh bank Syariah dilakukan secara ketat dengan menganalisis aspekaspek yang berhubungan dengan kemampuan calon nasabah untuk dapat memenuhi kewajibannya kepada bank Syari'ah.

Jika penilaian ketat yang dilakukan oleh perbankan syariah dirasa memenuhi syarat, maka pembiayaan mudharabah dituangkan dalam bentuk perjanjian dengan akta notariil. Akta dalam bentuk ini terasa perlu karena akta notariil mempunyai nilai alat bukti yang paling kuat diantara akta yang lain. Dalam akta notariil ini perbankan syariah dan nasabah yang dibiayai dengan mudharabah antara lain mengatur hubungan di antara mereka sedemikian rupa sehingga terjadi hubungan hukum yang saling mengikat antara pihak perbankan dengan pihak nasabah. Hubungan hukum yang dibangun dengan akta notariil diharapkan dapat memperkokoh hubungan yang dibangun secara moralitas.

Hubungan antara perbankan syariah dengan nasabah yang dibiayai dengan mudharabah yang dilakukan dengan perjanjian notariil bukan berarti bahwa pembiayaan mudharabah tidak mempunyai dasar hubungan moralitas. Hubungan secara hukum yang dituangkan dalam perjanjian notariil dalam taraf tertentu dibangun dengan landasan moral, yaitu dengan adanya penilaian tentang calon nasabah. Jika penialain secara moral dirasakan memenuhi persyaratan yang ditentukan, maka untuk memperkokoh hubungan perbankan dengan nasabah yang dibiaya dengan mudharabah dilakukan dengan akta notariil.

Melalui proses yang demikian itulah maka diharapkan nasabah yang dibiayai dengan mudharabah dapat melaksanakan pembiayaan yang diberikan oleh perbankan syariah dengan baik. Nasabah dapat menggunakan dana mudharabah sesuai dengaan apa yang telah disepakati dalam perjanjian yang dilakukan dengan akta notariil tersebut. Dengan demikian pelaksanaan pembiayaan mudharabah sebagaimana yang ditentukan dengan akta notariil didasarkan pada nilai-nilai moral yang telah sebelumnya dibangun.

cara demikian dilakukan agar nasabah yang dibiayai dengan mudharabah mentaati perjanjian yang dilakukan dengan akta notariil tersebut tidak semata-mata melihat secara hukum dalam kaitannya dengan hak dan kewajiban saja, tetapi didasrkan pada hubungan tanggung jawab menjaga hubungan mudharabah yang telah disepakatinya. Dengan demikian dana yang diterima dalam bentuk pembiayaan mudharabah tidak sekedar dilihat dari aspek ekonomis semata-mata, tetapi juga ada aspek tanggung jawab religius.

b. Adanya persyaratan jaminan

Untuk mengurasi resiko perbankan dalam memberikan pembiayaan mudharabah bank syariah selalu menyaratkan adanya jaminan kebendaan sebagai suatu keharusan. Jaminan kebendaan ini berkaitan dengan pemberian mudharabah dalam bentuk kebendaan (modal) sebagai amanah yang perlu dipertanggung jawabkan secara kebendaan pula. oleh karena 
itu meskipun pemberian pembiayaan mudharabah merupakan kerjasama, namun perbankan syariah tidak akan memberikan pembiayaan mudharabah tanpa adanya jaminan kebendaan.

Jaminan ini merupakan bentuk pertanggungjawaban secara hukum atas di pembiayan mudharabah oleh perbankan syariah, maka pemberian jaminan oleh nasabah kepada perbankan syariah dilakukan dengan akta notaris. Akta demikian sebagai bentuk keharusan karena meskipun bukan sebagai alat bukti yang sempurna, namun secara hukum akta inilah yang mempunyai kekuatan sebagai alat bukti yang paling kuat di antara alat bukti yang lain

Meskipun dasar falsafah mudharabah adalah kerjasama yang menempatkan posisi pemilik dana (perbankan) mempunyai kedudukan yang sederajat dengan nasabah yang dibiayai dengan mudharabah, sehingga tidak perlu ada jaminan, namun meskipun perbankan Syariah mensyaratkan jaminan dalam posisi bukan untuk menjamin pembiayaan mudharabah.

Jaminan dalam mudharabah ini bukan untuk menjamin kepastian pengembalian pembiayaan dan/atau keuntungan dari nasabah kepada perbankan syariah. Jaminan hanya berfungsi untuk menjamin bahwa nasabah akan mentaati perjanjian yang telah disepakati bersama. oleh karena itu jika usaha yang dibiayai dengan mudharabah mengalami kerugian dan kerugian tersebut adalah murni, bukan karena kelalaian atau pelanggaran perjanjian atau melakukan penipuan, maka bank syariah yang akan menanggung kerugian modal mudharabah tersebut. Jaminan tidak dapat dijual untuk menutup kerugian. Akan tetapi jika kerugian nasabah yang dibiayai dengan mudharabah disebabkan karena kelalaian atau pelanggaran perjanjian atau melakukan penipuan, maka jaminan dapat dijual oleh perbankan syariah (dengan prosedur yang ditentukan) untuk menutup kerugian maupun keuntungan yang dapat diperoleh sekiranya nasabah tidak melanggar perjanjian, atau kelalaian atau melakukan penipuan.

5. Model perjanjian ideal bagi perbankan syariah dalam memberikan pembiayaan mudharabah kepada nasabah.

a. Bidang usaha yang layak dibiayai dengan mudharabah

Sistem perbankan di Indonesia yang menjadikan perbankan hanya sebagai lembaga keuangan murni menimbulkan persoalan penerapan pranata hukum Islam yang kurang efektif. Penerapan hukum Islam dalam perbankan yang hanya dapat melakukan usaha dalam dunia keuangan saja seperti di Indonesia ini dalam taraf tertentu membatasi ruang gerak perbankan syariah di Indonesia dalam menerapkan hukum yang tidak bertentangan dengan syariah.

Dalam dunia keuangan yang demikian, Penerapan hukum Islam kemudian dilakukan sedemikian rupa rumit daan berbelit-belit hanya sekedar untuk memenuhi prosedur yang harus dilakukan agar memenuhi persyaratan yang diatur di dalam hukum Islam. Persoalannya bukan sekedar apakah proses dan prosedur yang dilakukan memenuhi ukuran kesyariahan atau tidak, tetapi sampai kepada persoalan apakah efisien dan efektif atau tidak pembiayaan-pembiayaan yang dilakukan oleh perbankan Syariah. oleh karena itu menjadi dapat difahami munculnya akibat bahwa perbankan syariah lebih mahal dari perbankan konvensional.

Pembiayaan yang menggunakan pranata mudharabah tidak dapat digunakan untuk membiayai semua kebutuhan yang ada dan menjadi tuntutan dari masyarakat. Hanya bidang-bidang usaha tertentu saja yang memenuhi syarat untuk dibiayai mudharabah. Hal ini dapat difahami karena secara konseptual mudharabah memang sebuah pranata untuk 
memenuhi kebutuhan dalam dunia ekonomi riil tertentu. oleh karena itu mudharabah memang hanya layak untuk pembiayaan pembiayaan tertentu saja.

Dari bidang-bidang ekonomi yang ada dalam dunia bisnis yang ada dan berkembang di dalam masyarakat, maka bidang usaha yang layak secara riil untuk dibiayai dengan pembiayaan mudharabah adalah

1) Bidang usaha proyek.

Proyek-proyek layak dibiayai oleh perbankan syariah dengan mudharabah karena proyek-proyek merupakan pembiayaan modal jangka pendek. Pembiayaan mudharabah dalam jangka pendek dirasa lebih mudah untuk direalisasi. Pembiayaan mudharabah dalam jangka pendek ini dirasakan oleh perbankan dapat mengurangi tingkat resiko yang resiko. Pembiayaan jangka pendek relatife mempunyai resiko yang yang lebih rendah dari pada mudharabah yang jangka panjang. Hal ini disebabkan:

(a) Mudah dalam pengawasan.

(b) Mudah pelaksanaan mudharabah

(c) Mudah mengakhiri mudharabah

(d) Mudah menghitung laba rugi

(e) Mudah menghitung bagi hasil.

Meskipun pembiayaan mudharabah untuk proyekproyek jangka pendek dirasakan mudah dalam mewujudkan efektivitas pembiayaan, namun dalam kenyataan sektor usaha yang dibiayai dengan mudharabah juga sedikit, yaitu hanya sekitar $30 \%$

2) Bidang usaha keuangan

Penggunaan pranata hukum mudharabah dalam dunia keuangan perbankan syariah dalam bentuk pembiayaan mudharabah secara ideal diharapkan akan membiayai sektor-sektor usaha riil yang ada din dalam masyarakat, sehingga dapat menggerakkan sektor riil. Hal ini ternyata tidak sepenuhnya dapat dilakukan oleh perbankan syariah, karena permohonan-permohonan dari masyarakat untuk dibiayai dengan mudharabah relatif sedikit. Sedikitnya permohonan dari masyarakat terhadap pembiayaan mudharabah ini dapat difahami karena pembiayaan dengan model mudharabah ini relatif baru dalam dunia perbankan sehingga kurang banyak diketahui secara baik oleh masyarakat.

Rendahnya permohonan dari masyarakat untuk dibiayai dengan mudharabah menjadikan perbankan syariah melirik lembaga keuangan mikro dan koperasi untuk diberikan pembiayaan mudharabah. Lembaga keuangan mikro dan koperasi yang dibiayai dengan mudharabah ini bukan usaha ekonomi riil, tetapi usaha jasa keuangan sebagaimana perbankan. Dengan demikian sektor keuangan membiayai mudharabah kepada sektor keuangan. oleh karena itu pembiyaan mudharabah oleh perbankan syariah tidak secara langsung dapat menggerakkan sektor ekonomi riil sebagaimana yang dikonsepkan oleh para ahli hukum Islam.

Secara hukum Islam, pembiayaan mudharabah oleh perbankan syariah kepada lembaga keuangan dan koperasi yang menyelenggarakan jasa keuangan adalah tidak dilarang dan syah-syah saja selama memenuhi semua persyarakat dan unsur-unsur yang ditentukan untuk sebuah transaksi mudharabah.

Perbankan syariah dalam memberikan pembiayaan mudharabah kepada lembaga 
keuangan mikro atau koperasi yang menyelenggarakan usaha jasa keuangan, tentu saja hanya terhadap lembaga keuangan mikro atau koperasi yang melakukan usaha keuangan yang menggunakan prinsip-prinsip syariah. Artinya pemberian pembiayaan mudharabah hanya terhadap lembaga keuangan mikro dan koperasi yang syariah.

Pemberian pembiayaan mudharabah kepada Lembaga keuangan mikro dan koperasi yang tidak syariah, secara hukum islam dilarang karena dikhawatirkan akan mengandung unsur-unsur riba dalam pengelolaan keuangan yang diberikan oleh perbankan syariah.

b. Nasabah yang layak dibiayai dengan mudharabah

1) Nasabah pribadi perorangan

S e c a r h u k u , pembiayan mudharabah tidak mensyaratkan nasabah dalam menerima pembiayaan, kecuali adanya persyaratan tentang keahlian atau profesionalitas usaha yang dibiayai dengan mudharabah tersebut. Persyaratan keahlian atau profesionalitas merupakan syarat mutlak untuk adanya mudharabah. Sebab dengan dana yang diberikan dapat digunakan dalam kegiatan usaha untuk mencari keuntungan.. Tanpa adanya keahlian, maka tidak mungkin dapat diberikan pembiayaan mudharabah. Pembiayaan mudharabah kepada orang yang tidak mempunyai keahlian atau profesinalitassesuai dengan bidang usaha yang dibiayai dengan mudharabah tidak akan efektif dalam menjalankan mudharabah.

Dengan demikian calon nasabah yang mempunyai keahlian atau profesionalitas tertentu dapat mengajukan pembiayaan mudharabah.
Dalam posisinya sebagai pribadi perorangan, seorang pengusaha yang mempunyai keahlian dan profesionalitas tertentu dapat mengajukan dan mendapatkan pembiayaan mudharabah dari perbankan syariah.

Selain secara pribadi perorangan, perbankan syariah memberikan pembiayaan kepada badan badan hukum sebagai subyek hukum. oleh karena itu badan hukum Perseroan terbatas atau kopertasi atau yayasan dapat mengajukan dan mendapatkan pembiayaan mudharabah dari perbankan Syariah.

2) Nasabah badan hukum

Perbankan syariah selain memberikan pembiayaan mudharabah kepada pribadi perorangan, dapat memberikan pembiayaan mudharabah kepada nasabah yang berbentuk badan hukum. Selama ini perbankan Syariah lebih banyak memberikan pembiayaan kepada badan hukum dari peda perorangan. Ini bukan berarti bahwa perbankan syariah tidak mempercayai untuk memberikan pembiayaan kepada perorangan. Sebab dalam kenyataan permintaan pembiayaan mudharabah dari pribadi perorangan relatif sangat sedikit. oleh karena itu pemberian pembiayaan memang banyak diberikan kepada badan hukum.

Pemberian pembiayaan kepada badan hukum memang dirasakan dirasakan oleh pihak perbankan sebagai lebih dapat dipercaya untuk dapat dipertanggung jawabkan. Bukan karena semata-mata orang banyak lebih dapat dipertanggungjawabkan untuk dipercaya dari pada pribadi perorangan, tetapi lebih disebabkan karena perusahaan mempunyai sistem operasional yang memungkinkan dapat 
mengelola pembiayaan mudharabah secara bertanggung jawab.

\section{Simpulan}

Berdasarkan hasil penelitian yang telah dilakukan dapat ditarik beberapa kesimpulan:

1. Pembiayaan mudharabah relatif sangat sedikit, tidak sebagaimana yang diharapkan oleh para ilmuwan Islam pada masa pembentukan bank Islam karena beberapa faktor yaitu faktor internal, faktor eksternal, dan faktor sistem. Faktor internal antara lain disebabkan karena resiko yang tinggi dalam pembiayaan dan pengalamam menerapkan mudharabah yang masih relatif sedikit. Faktor eksternal antara lain disebabkan oleh permohonan pembiayaan yang sedikit, budaya pinjam-meminjam dan utang-piutang dimasyarakat, kurang budaya bekerjasama dalam mencari keuntungan, pelaku usaha lebih merasa nyaman berspekulasi secara sendiri-sendiri, dan rumitnya pembiayaan mudharabah. Faktor sistem diantaranya sistem perbankan nasional yang melarang lembaga perbankan melakukan kegiatan usaha diluar sector keuangan, pengawasan yang ketat terhadap pembiayaan mudharabah yang dialkukan Bank Indonesia, dan kesulitan menggunakan pranata hukum riil didalam dunia keuangan.

2. Efektifitas pembiayaan mudharabah dapat dilakukan dengan beberapa upaya diantaranya pemilihan jenis usaha yang dibiayai mudharabah, pemilihan jenis mudharabah muqayyadah, pemilihan subjek hukum yang dibiayai dengan mudharabah, pengawasan pembiayaan mudahrabah.

3. Bentuk perlindungan hukum yang ideal untuk dijadikan model dalam mengurangi tingkat resiko yang dihadapi bank syariah antara lain dengan pemberian pembiayaan mudaharabah dengan akta nota riil dan adanya persyaratan jaminan sebagai bentuk kehati-hatian.

4. Bidang usaha yang layak secara riil untuk dibiayai dengan pembiayaan mudharabah adalah bidang usaha proyek dan bidang usaha keuangan.

\section{E. Saran}

Beberapa saran yang dapat peneliti usulkan antara lain:

1. Perlunya mitigasi resiko bagi pihak bank syariah terhadap pembiayaan mudharabah sebagai salah satu upaya untuk meningkatkan pembiayaan mudharabah sehingga menjadi salah satu produk andalan yang ada di bank syariah.

2. Perlu dilakukan proses sosialisasi kepada masyarakat secara lebih mendalam mengenai karakteristik pembiayaan mudharabah agar masyarakat khususnya pelaku usaha dapat mengakses jenis pembiayaan ini untuk peningkatan usaha mengingat sedikitnya permintaan terhadap pembiayaan mudharabah.

3. Sistem pengawasan Bank Indonesia perlu ditingkatkan berkaitan dengan pembiayaan mudharabah sehingga akan mendukung peningkatan angka pembiayaan mudharabah yang ada di bank syariah. 


\section{daftar Pustaka}

Anonim. Islamic Banking Practice from the practitioner's Perspective. Kuala Lumpur: Bank Islam Malaysia Berhard, 1994.

Anonim. Himpunan Fatwa Dewan Syariah Nasional. Jakarta: Dewan Sariah Nasional Majelis Ulama Indonesia dan Bank Indonesia, 2001.

Antonio, Muhammad Syafi'i, Bank Syariah dari Teori ke Praktek. Jakarta: Gema Insani Press. 2001.

Dewi, Gemala, dkk. Hukum Perikatan Islam Di Indonesia, Jakarta: Kencana. 2005.

Hanafi, Syafiq Muhamad dam Ahmad Sobirin. Relevansi Ajaran Agama DalamAktifitas Ekonomi. Makalah Pada Simposium Nasional Ekonomi 23-4 Maret. Yogyakarta. 2002.

Haroen, Nasroen, Fiqih Muamalah. Jakarta:Gaya Media Pratama. 2000.

Lewis, Mervin K dan Latifa M. Algoud. Islamic Banking. Massacussets: Edward Elgar Publishing. 2001.

Niazi, Liaquat Ali Khan, Islamic Law Of Contract. Lahore: Research cell Dyal Sing Tust Library. 1990.

Rahman, Afzalur. Doktrin Ekonomi Islam Jilid 4. Yogyakarta: Dana Bhakti Wakaf. 1996.

Scacht, J, An Introduction To Islamic Law. London: oxford University Press.1964.

Siddiqi, Muhammad Nejatullah, Partnership And Profit Sharing in Islamic Law. Leceister:The Islamic Foundation. 1985.

Soekanto, Soerjono dan Sri Mamuji. Penelitian Hukum Normatif Suatu Tinjauan Singkat. Jakarta: Rajawali Press. 1986.

Tyzer. B.A.L. The Majelle Being An English Translation of Majjalahel-Ahkam-al-Adliya And Complete Code On Islamic Civil Law. Lahore: LawPublishing company. 